\title{
Impilikasi yuridis putusan pailit terhadap profesi notaris menurut peraturan perundang-undangan di Indonesia
}

\author{
Adheria Juniresta ${ }^{1}$, Budi Santoso ${ }^{2}$, Hanif Nur Widhiyanti ${ }^{3}$
}

${ }^{1}$ Adheria Juniresta; Magister Hukum Universitas Brawijaya; Jalan MT. Haryono 169 Malang; 65145; Jawa Timur; Indonesia.

${ }^{2}$ Budi Santoso; Fakultas Hukum Universitas Brawijaya; Jalan MT. Haryono 169 Malang; 65145; Jawa Timur; Indonesia.

${ }^{3}$ Hanif Nur Widhiyanti; Fakultas Hukum Universitas Brawijaya; Jalan MT. Haryono 169 Malang; 65145; Jawa Timur; Indonesia.

\begin{tabular}{l} 
A R T I C L E I N F O \\
\hline Article history: \\
Received 2020-12-24 \\
Received in revised form \\
2021-02-14 \\
Accepted 2021-04-01 \\
\hline
\end{tabular}

Kata kunci:

Notaris; Pailit; Akibat Hukum.

Keywords:

Notary; Bankrupt; Legal Due.

DOI: https://doi.org/10.26905/ idjch.v12i1.5783.

\section{How to cite item:}

Juniresta, A., Santoso, B., Widhiyanti, HN. (2021).

Impilikasi yuridis putusan pailit terhadap profesi notaris menurut peraturan perundangundangan di Indonesia. Jurnal Cakrawala Hukum, 12(1), 1-10. doi:10.26905/idjch.v12i1.5783.

Corresponding Author:

* Adheria Juniresta.

E-mail address: adheriajuniresta@gmail.com.

\section{Abstrak}

Tulisan ini bertujuan untuk menganalisis kesesuaian pengaturan mengenai akibat hukum bagi notaris yang dinyatakan pailit. Jenis penelitian hukum normatif ini menggunakan pendekatan perundang-undangan. Berdasarkan hasil pembahasan diperoleh kesimpulan bahwa ketentuan mengenai akibat hukum bagi notaris yang dinyatakan pailit dalam UUJN merupaka lex spesialis dari ketentuan serupa dalam UUK dan PKPU. Hal ini juga dikarenakan konsep pailit dalam UUJN berbeda dengan konsep pailit pada UUK dan PKPU. Pailit pada UUK dan PKPU mengesampingkan jabatan dari seseorang yang dipailitkan, namun pailit dalam UUJN tersebut dapat menyangkut jabatan seseorang sebagai seorang Notaris apabila pailit tersebut adalah akibat dari kesalahan yang dilakukan seseorang dalam jabatannya sebagai Notaris. Kemudian akibat hukum yang dapat diterima oleh Notaris yang dinyatakan pailit adalah pemberhentian jabatan sebagai seorang Notaris. Notaris bisa dituntut pemenuhan penggantian biaya, ganti rugi maupun bunga oleh para pihak atas dasar perbuatan melawan hukum. Pengaturan kepailitan yang dimaksud dalam UUJN bersifat khusus ditujukan terhadap kedudukan notaris sebagai subyek hukum yang mewakili orang dan juga sebagai wakil dari jabatannya yang melaksanakan kewenangan dalam pembuatan akta otentik.

\section{Abstract}

This paper aims to understand the suitability of the regulations regarding the legal consequences for notaries who are declared bankrupt. This type of normative legal research uses a statutory approach. Based on the results of the discussion, it was 
concluded that the provisions regarding legal consequences for notaries who were declared bankrupt in UUJN were specialist lex of similar provisions in the UUK and PKPU. This is also because the bankruptcy concept in UUJN is different from the bankruptcy concept in UUK and PKPU. Bankruptcy under UUK and PKPU overrides the position of a person who is bankrupt, however bankruptcy in the UUJN may involve a person's position as a Notary if the bankruptcy is the result of an error committed by someone in his / her position as a Notary Public. Then the legal consequence that can be accepted by a Notary who is declared bankrupt is the dismissal of his position as a Notary Public. Notaries can be sued for the fulfillment of reimbursement of expenses, compensation or interest by the parties on the basis of acts against the law. The bankruptcy regulation referred to in the UUJN is specifically aimed at the notary's position as a legal subject who represents a person and also as a representative of his position who exercises the authority in making authentic deeds.

\section{Latar Belakang}

Notaris adalah pejabat umum yang berhak untuk mengeluarkan akta otentik dan wewenang lainnya yang diatur pada Undang-Undang Republik Indonesia Nomor 2 Tahun 2014 Tentang Perubahan Atas Undang-Undang Republik Indonesia Nomor 30 Tahun 2004 Tentang Jabatan Notaris (UUJN). Notaris adalah suatu jabatan yang bertugas menjalankan beberapa fungsi Negara di ranah hukum perdata dengan kewenangan untuk membuat akta otentik, yang berdasar kepada keterangan pihak-pihak yang bersangkutan untuk menghadap kepada notaris (Purwaningsih, 2011). Notaris mempunyai kewenangan dalam pembuatan akta otentik terkait semua perjanjian, perbuatan, dan penetapan yang diwajibkan oleh UU dan/atau yang menjadi kehendak oleh yang mempunyai kepentingan dengan menyatakan untuk dituangkan melaui akta otentik, guna menjamin adanya kepastian hukum terkait pembuatan tanggal akta, penyimpanan akta, pemberian grosse, serta salinan dan kutipan dari akta. Pembuatan akta seluruhnya, tidak ada penugasan atau pengecualian terhadap pejabat lain atau orang lain yang telah ditetapkan oleh undang-undang. Selain kewenangan sebagaimana yang telah dituangkan di atas, se- orang notaris, wajib untuk bertindak amanah, kredibel, saksama, mandiri, tidak memihak, dan bertanggung jawab serta memberi bantuan pada masyarakat yang membutuhkan jasa tersebut dengan sebaik-baiknya.

Seorang notaris tidak bermaksud untuk mendapat keuntungan, notaris melakukan pekerjaan bersumber pada kualitas pribadi atau keahliannya. Notaris menerima pendapatan atas kemampuan jasa hukum yang diberikan yang sesuai dengan kewenangannya, tetapi jasa hukum yang diberikan bukan untuk mencari keuntungan, besar atau kecilnya pendapatan yang di dapat oleh notaris didasari atas nilai ekonomis \& nilai sosiologis, berdasarkan setiap akta yang telah dibuatnya. Kewajiban seorang notaris adalah memberikan jasa hukum di ranah kenotariatan dengan biaya gratis terhadap masyarakat yang tidak mampu. Seorang notaris yang melaksanakan bisnis atau usaha di luar jabatannya, penyebab dipailitkannya orang yang berprofesi sebagai notaris, apabila terpenuhinya syarat yang diatur pada Pasal 2 Ayat 1 UUK dan PKPU.

Perbedaan prinsip menurut Polak dan Molengraaf antara pekerjaan sebagai seorang notaris dan pekerjaan menjalankan perusahaan. 
Seluruh perbuatan-perbuatan, tidak terputus-putus dalam pelaksanaannya, secara transparansi, dalam kedudukan tertentu dengan tujuan mencari keuntungan itulah yang dimaksud perusahaan. Sedangkan menurut Molengraaf, Semua perbuatan yang dilaksanakan dengan terus-menerus, keluar dalam tindakannya, untuk memperoleh pendapatan, melalui perniagaan barang-barang, penyerahan barang-barang, atau perjanjian perdagangan yang diadakannya (Sutcipto, 1995).

Menurut pendapat Polak, unsur laba pada perusahaan adalah unsur mutlak, sedangkan bukan unsur mutlak pada pekerjaan notaris. Pekerjaan Notaris bukan ditujukan untuk mencari untunga, pekerjaannya berdasar atas kualitas keahliannya, walupun ia dibayar atas jasanya, tetapi UUJN sudah mengatur nominal tersebut, yang membuat notaris tidak dapat menentukan sendiri harga jasanya. Tidak ada pembukuan dalam Notaris. sehingga mekanisme kerja yang dijalankan tersbut, notaris berbeda dengan perusahaan.

Berdasarkan Pasal 2 Ayat (1) UUK dan PKPU orang pribadi yang berprofesi sebagai notaris yang melakukan kegiatan usaha lain bisa dipailitkan. Tetapi yang menjadi permasalahan apakah ia harus diberhentikan dari jabatannya sebagai notaris. Peristiwa hukum ini dapat menimbulkan adanya ketidakpastian hukum. Dalam praktik sering terdapat permasalahan hukum, di mana ketika dipertemukan dengan norma yang mengaturnya, kadang kala kabur atau tidak sempurna, yang berakibat pembiasan penafsiran yang menimbulkan ketidakpastian hukum (Semedi, 2013).

Kepastian hukum adalah undang-undang yang dijadikan dasar dalam penerapannya tidak memiliki penafsiran ganda (Wisnuwardhani, 2017). Aspek konsistensi juga terkandung dalam unsurunsur kepastian hukum. Jika membaca isi Pasal 21 juncto Pasal 24 ayat (1) UUK dan PKPU, menye- butkan kepailitan mencangkup seluruh kekayaan debitur ketika putusan pernyataan pailit diucapkan, serta segala sesuatu yang didapatkan dalam kurun waktu kepailitan berlangsung, dan debitur menerima akibat atas kehilangan haknya untuk menguasai dan mengurus kekayaannya yang termasuk di dalam harta pailit, pada saat tanggal putusan pernyataan pailit diucapkan. Kehilangan haknya tersebut hanya terbatas pada harta kekayaannya dan bukan temasuk status pribadinya. Debitur yang berada dalam keadaan pailit tidak kehilangan hak-hak keperdataannya selaku WNI, seperti hak politik, dan hak privat lainnya (Shubhan, 2008).

Akibat hukum terhadap notaris yang telah dinyatakan pailit oleh pengadilan pada Pasal 12 huruf a UUJN, berbeda dengan ketentuan yang terdapat pada Pasal 24 ayat (1) UUK dan PKPU. Akibat hukum kepailitan pada UUK dan PKPU tidaklah seperti yang diatur pada UUJN, dimana sampai dapat memberhentikan seseorang dari jabatannya. UUK dan PKPU menyatakan debitur dikategorikan tidak cakap dalam mengurus harta kekayaannya saja sehingga debitur tetap diperbolehkan melaksanakan perbuatan hukum yang lain. Pasal 12 huruf a UUJN menyebutkan notaris yang dinyatakan pailit berdasarkan putusan pengadilan dan sudah memperoleh kekuatan hukum tetap diberhentikan dengan tidak hormat dari jabatannya (Firmansyah, 2017). Jika membaca pasal tersebut, tidak dijelaskan apakah notaris diberhentikan dengan tidak hormat dari jabatannya karena dinyatakan pailit adalah karena menjalankan bisnis atau usaha dalam jabatannya sebagai notaris. Pada substansi Pasal 12 huruf a UUJN tidak dijelaskan dengan rinci apa kriteria seorang notaris dinyatakan pailit atau termasuk dalam kategori penundaan pembayaran (Surseance Van Betaling) tunduk pula pada UUK dan PKPU (Adjie, 2008). 
Sebagaimana telah diuraikan diatas, Notaris sangat dirugikan jika sanksi yang diberikan berlndaskan Pasal 12 huruf a UUJN j. Sebaiknya Majelis Pengawas daerah, Majelis Pengawas Wilayah, Majelis Pengwasa Pusat, dan Menteri sebagai Majelsi Pengawas, asas keadilan dan manfaat harus dujadikan dasar dalam memberikan sanksi disamping itu kelangsungan hidup notaris harus diperhatikan. Penerapan sanksi dan pemberhentian Notaris hendaknya mengikut sertakan Majelis Pengawas Notaris, Menteri dan Ikatan Notaris Indonesia (INI) karena mereka merupakan wadah organisasi profesi notaris. untuk dimintai pendapat, pertimbangan dan dasar hukumnya. Berdasarkan uraian latar belakang di atas, maka dapat ditentukan rumusan masalah: Bagaimana kesesuaian pengaturan mengenai akibat hukum bagi notaris yang dinyatakan pailit antara UUJN, UU Kepailitan dan PKPU.

\section{Metode}

Metode Penelitian dalam penulisan artikel ini adalah metode penelitian doctrinal atau biasa disebut dengan penelitian hukum normatif. Metode penelitian normative mengutip pendapat Terry Hutchinson yang dikutip oleh Peter Mahmud adalah penelitian sistematis untuk menjelaskan secara sistematis aturan suatu kategori hukum tertentu serta mengalisis hubungan antara peraturan atas kesulitan serta memprediksi pembangunan hukum ke depan (Marzuki, 2011). Dalam metode penelitian normative ini digunakan metode pendekatan peraturan perundang-undangan (statute approach) dan pendekatan teoritis (theoretical approach). Pendekatan peraturan perundang-undangan digunakan untuk mengetahui impilikasi yuridis putusan pailit terhadap profesi notaris menurut undang-undang jabatan notaris, undang-undang kepailitan dan penundaan kewajiban pembayaran utang. Pendekatan teoritis digunakan sebagai acuan dalam merumuskan kepastian hukum dalam pembentukan peraturan perundang-undangan.

\section{Pembahasan}

3.1 Analisis kesesuaian pengaturan putusan pailit terhadap notaris menurut UndangUndang Jabatan Notaris, Undang-Undang Kepailitan dan Penundaan Kewajiban Pembayaran Utang

a. Kesesuaian pengaturan putusan pailit terhadap notaris menurut UUJN serta UUK dan PKPU berdasarkan teori kepastian hukum

Berdasarkan teori kepastian hukum dapat dikatakan bahwa suatu undang-undang yang dibuat haruslah memperhatikan ketentuan peraturan perundang-undangan yang lainnya, hal tersebut dimaksudkan agar undang-undang tidak menimbulkan konflik norma dengan peraturan perundang-undangan yang lainnya dan undangundang tersebut tidak menimbulkan multi tafsir (penafsiran yang berbeda-beda satu dengan yang lain). Dalam hal ini aturan hukum terkait dengan pengaturan putusan pailit terhadap Notaris berdasarkan UUJN bertentangan dengan aturan putusan pailit terhadap Notaris yang diatur berdasatkan UUK dan PKPU berbeda.

Asas ini pada dasarnya menyatakan bahwa peraturan perundang-undangan yang lebih khusus terhadap suatu permasalahan tertentu mengesampingkan peraturan perundang-undangan yang lebih umum terhadap suatu permasalahan yang khusus (Sudarsono, 2007). Permasalahan yang terdapat dalam penelitian ini adalah pengaturan putusan pailit terhadap Notaris, untuk itu berdasarkan asas lex specialis derogat legi generalis maka dalam permasalahan ini putusan pailit yang dikhususkan terhadap Notaris seharusnya menggunakan ketentuan yang terdapat dalam UUJN dan mengesampingkan ketentuan dalam UUK dan PKPU yang memiliki sifat yang lebih general karena mengatur kepailitan tersebut secara lebih umum. 
Pailit dalam UUJN dan pailit yang diatur dalam UUK dan PKPU adalah berbeda. Perbedaan tersebut terdapat pada subjek hukum pailit secara khusus adalah orang perorangan. Subjek hukum dalam UUK dan PKPU adalah orang perorangan dan tidak termasuk dengan jabatan yang mereka miliki, sehingga terjadinya kepailitan terhadap seseorang tidak akan berakibat secara langsung pada jabatan mereka. Namun berbeda dengan subjek hukum adalam UUK dan PKPU tersebut subjek hukum orang dan perorangan dalam UUJN menyangkut secara langsung terhadap jabatan mereka dalam hal ini adalah Jabatan Notaris.

Kesalahan Notaris dapat berupa kesalahan dalam menjamin kepastian tanggal terkait dengan pembuatan akta Notariil. Oleh karena kesalahan yang dilakukan seseorang dalam Jabatannya sebagai Notaris tersebut maka seorang Notaris juga harus mempertanggung jawabkannya dalam jabatannya secara khusus sebagai seorang Notaris. Oleh karena itu apabila Notaris tidak dapat memberikan ganti kerugian dalam jumlah tertentu terhadap orang yang tidak diuntungkan pada akta yang dibuatnya maka Notaris haruslah mengajukan pailit dimana pailit tersebut dilakukan terhadap pribadi serta jabatannya sebagai seorang Notaris secara berkesinambungan.

Berdasarkan pertentangan mengenai pengaturan putusan pailit terhadap Notaris menurut UUJN serta UUK dan PKPU tersebut adalah dengan menggunakan asas lex specialis derogat legi generalis sehingga peraturan mengenai pailit dalam UUJN yang diutamakan dan mengesampingkan ketentuan pailit dalam UUK dan PKPU. Hal ini juga dikarenakan konsep pailit dalam UUJN berbeda dengan konsep pailit pada UUK dan PKPU dimana pailit dalam UUK dan PKPU mengesampingkan jabatan dari seseorang yang dipailitkan namun dalam UUJN pailit tersebut dapat menyangkut jabatan seseorang sebagai seorang Notaris apabila pailit tersebut adalah akibat dari kesalahan yang dilakukan seseorang dalam jabatannya sebagai Notaris.

\section{b. Kesesuaian pengaturan putusan pailit terhadap notaris menurut UUJN serta UUK dan PKPU berdasarkan teori keadilan}

Keadilan menurut Aristoteles terdiri dari dua klasifikasi yang pertama keadilan distributief dan yang kedua keadilan commutatief, keadilan yang diberikan sesuai dengan poris dan prestasinya itulah yang disebut keadilan distributif, sedangkan keadilan commutatief adalah pemberian keseimbangan atau sama rata kepada setiap orang dengan tidak adanya perbedaan di setiap orang. Pada zaman yang berkembang ini konsep mengenai keadilan ini banyak menjadi gagasan untuk mengambil suatu kebijakan, dimana masalah mengenai keadilan menjadi sangat kompleks yang melibatkan para ahli hukum, ekonomi, politik dan sosiologi serta banyak orang yang berpendapat mengenai apa itu keadilan dan mereka pun dapat menafsirkan keadilan.

Keadilan yang tepat apabila dipergunakan dalam permasalahan ini adalah keadilan distributif. Oleh karena itu apa yang disebut dengan keadilan tidaklah sama antara satu dengan yang lain, begitu pula dengan Notaris. Melihat dari uraian mengenai asas lex specialis derogate legi generalis tersebut dalam sub-bab sebelumnya, dapat diketahui bahwa kedudukan Notaris diatur dengan peraturan perundang-undangan tersendiri yaitu UUJN, walaupun UUJN tersebut memiliki kedudukan yang sama dengan UUK dan PKPU namun dalam sistematika perundang-undangan UUJN memiliki kedudukan yang lebih khusus dari UUK dan PKPU dalam mengatur kepailitan kepada Jabatan Notaris. Oleh karenanya sudah sewajarnya bahwa seorang Notaris yang mengalami kepailitan atas jabatannya mempunyai akibat yang berbeda dengan kepailitan yang dialami oleh orang-orang pada umumnya.

Kepailitan kepada Notaris secara khusus dikenakan kepada jabatannya sebagai seorang Notaris, hal tersebut berbeda dengan kepailitan pada umumnya yang dikenakan kepada orang 
sebagai subjek hukum. Kepailitan kepada Notaris disebabkan karena pemberian ganti kerugian akibat kesalahan yang diperbuat oleh Notaris dalam menjalankan jabatannya sehingga menimbulkan kerugian bagi pihak lain, sedangkan kepailitan pada umumnya timbul akibat dari ketidaksanggupan seseorang untuk melakukan pembayaran terhadap utangnya. Untuk itu dapat diketahui bahwa kepailitan kepada Jabatan Notaris yang diatur dalam UUJN secara keseluruhan berbeda dengan kepailitan pada umumnya yang diatur dalam UU Kepailitan dan PKPU.

\subsection{Akibat hukum putusan pailit terhadap notaris menurut Undang-Undang Jabatan Notaris serta Undang-Undang Kepailitan dan Penundaan Kewajiban Pembayaran Utang}

Sita umum tersebut bukan untuk diperuntukkan kepentingan seorang atau beberapa orang kreditur saja, tetapi sita umum tersebut diperuntukkan dengan tujuan pencegahan penyitaan dan eksekusi untuk seluruh kreditur yang telah diminta secara perorangan. Mekanisme hukum yang dapat dilakukan oleh kreditur untuk menyelamatkan piutangnya dari debitur yang telah wanprestasi; (1) Gugatan perdata, dengan konsekuensi kepentingan penggugat atau kreditur saja yang terpenuhi terkait harta debitur yang disita, selanjutnya eksekusi terhadap pemenuhan piutangnya atas permohonan kreditur. Sedangkan kreditur yang tidak melakukan gugatan, maka kreditur tersbut, tidak dilindungi kepentingannya. (2) Melalui pengajuan permohonan pailit, dengan konsekuensi, status sita umum atas semua harta kekayaan debitur, sejak saat itu pula semua sita yang telah dilaksanakan dinyatakan gugur

Berdasarkan penjelasan mengenai pihakpihak yang dapat dinyatakan pailit, maka yang dapat dianalisa bahwa kepailitan yang diatur dalam Undang-Undang Nomor 37 Tahun 2004 tidak dapat diberlakukan untuk jabatan notaris (Pratiwi, 2020). Notaris bukan sebagai debitur yang paling sedikit memiliki dua kreditur serta jatuh tempo hutang yang belum dilunasinya. Secara pribadi seorang notaris diperbolehkan untuk mempunyai usaha yang lain, diluar jabatannya sebagai notaris, seperti; berdagang atau menjadi pengusaha yang bisa saja pada saat itu, yang bersangkutan berkedudukan sebagai debitur yang dapat dipailitkan.

Selanjutnya setelah permohonan kredit tersebut dikabulkan, ternyata notaris tidak mampu dan tidak dapat membayarnya, secara otomatis notaris tersebut dapat diajukan sebagai pihak yang pailit melalui Pengadilan Niaga dalam kapasitasnya sebagai notaris. Sedangkan terhadap notaris pembuat akta yang melakukan kesalahan, yang berakibat akta tersebut kehilangan otentisitasnya atau mengakibatkan batal demi hukum, maka kewajiban notaris untuk memberi ganti rugi atas putusan pengadilan sebagaimana dimaksud dalam Pasal 84 UUJN.

Menurut Joko Wilyono, notaris yang bersangkutan tidak dapat dipailitkan walaupun pada akhirnya notaris tersebut tidak dapat memenuhi seluruh kewajibannya dalam hal memberikan ganti rugi, sebab dalam kasus di atas tidak ditemukan unsur utang piutang, ganti kerugian timbul karena akibat adanya kesalahan, sehingga timbul kewajiban kepada pihak yang menimbulkan kesalahan untuk melakukan ganti rugi, sedangkan utang piutang timbul dari dua pihak yang melakukan perjanjian, dan menyebabkan kedua belah pihak terikat secara hukum melalui isi perjanjian tersebut, dan jika salah satu pihak melalaikan atau tidak melaksanakan isi kewajibannya, maka berakibat sanksi bagi pihak yang telah melalaikan. Sehingga terdapat 2 (dua) unsur yang menjadi syarat tidak terpenuhinya untuk dinyatakan pailit. Pertama, tidak ditemukan adanya utang, kedua, tidak ditemukan adanya perjanjian antara kedua belah pihak yang mengakibatkan adanya utang piutang tersebut. 


\section{Impilikasi yuridis putusan pailit terhadap profesi notaris menurut peraturan perundang-undangan di Indonesia}

Adheria Juniresta, Budi Santoso, Hanif Nur Widhiyanti

Dalam UUJN diatur mengenai dua jenis sanksiyang bisa diterapkan, antara lain (Adjie, 2008):

\section{a. Sanksi Perdata}

Sebagaimana yang tersebut dalam Pasal 84 UUJN, yaitu tindakan pelanggaran yang dilakukan oleh notaris terhadap ketentuan sebagaimana dimaksud dalam Pasal 16 ayat (1) huruf i, Pasal 16 ayat (1) huruf k, Pasal 41, Pasal 44, Pasal 48, Pasal 49, Pasal 50, Pasal 51, Pasal 52 yang mengakibatkan suatu akta hanya mempunyai kekuatan pembuktian sebagai akta di bawah tangan atau suatu akta menjadi batal demi hukum.

Pasal 84 UUJN telah disebutkan, akta yang tidak memenuhi syarat, menjadi akta yang mempunyai kekuatan pembuktian dapat dijadikan sebagai di akta bawah tangan atau akta termasuk dalam akta batal demi hukum, artinya akta tersebut serta-merta menjadi akta di bawah tangan atau batal demi hukum tanpa perlu pembuktian terlebih dahulu. Maka dalam hal ini tetap diperlukan adanya pihak yang menilai bahwa akta yang dibuat oleh notaris tersebut adalah akta otentik. Sebelum sampai pada tahap kesimpulan bahwa akta yang bersangkutan dapat dijadikan akta di bawah tangan ataupun dapat menjadi batal demi hukum, maka langkah awal yang harus ada adalah pembuktian. Bisa saja menurut beberapa pihak syaratnya tidak terpenuhi, tetapi telah memenuhi syarat menurut notaris, maka dengan demikian harus ada pembuktian bahwa akta yang bersangkutan dapat dinyatakan tidak memenuhi ketentuan pasal-pasal yang bersangkutan melalui ketentuan Pasal 84 UUJN.

Kekuatan pembuktian yang dimiliki akta di bawah tangan dan batal demi hukum, merupakan sesuatu yang berbeda. tidak ada penentuan terkait pasal-pasal dan batasan juga tidak diatur, untuk menentukannya bersifat alternatif. Akta yang berkekuatan pembuktian sebagai akta di bawah tangan dapat terjadi jika akta tersebut tidak memenuhi ketentuan sebagaimana tersebut dalam Pasal 1869
Kitab Undang-Undang Hukum Perdata (BW), karena: 1. pejabat umum yang bersangkutan tidak mempunyai wewenang; 2 . pejabat umum yang bersangkutan tidak mampu; 3. Bentuknya cacat.

Maka akta tersebut tidak dapat dikategorikan dan tidak dapat diperlakukan sebagai akta otentik, tetapi akta tersebut mempunyai kekuatan pembuktian sebagai akta di bawah tangan jika akta tersebut toleh para pihak telah ditandatangani. Sedangkan batasan-batasan akta notaris yang menjadi batal demi hukum apabila : 1. objek tertentu tidak dapat ditentukan; 2. Adanya sebab yang dilarang oleh peraturan perundang-undangan atau berlawanan dengan ketertiban umum atau kesusilaan.

Jaminan bahwa akta yang telah dibuatnya harus sesuai dan tidak bertentangan dengan Peraturan perundang-undangan dan melindungi kepentingan-kepentingan para pihak, harus diterpakan oleh setiap notaris. Keberlakuakn sanksi perdata terhadap perbuatan-perbuatan yang dapat menimbulkan kerugian bagi para pihak. Pelanggaran-pelanggaran terhadap ketentuan Pasal 84 UUJN yang berakibat akta otentik mengalami degradasi menjadi akta di bawah tangan atau menjadi batal demi hukum merupakan salah satu dari bentuk perbuatan melawan hukum yang diatur dalam Pasal 1365 Kitab Undang-Undang Hukum Perdata (BW).

Majelis Pengawas, notaris atau para pihak tidak bisa menilai akta tersebut, karena harus melalui mekanisme gugatan ke pengadilan umum. Tuduhan atas pelanggaran harus dibuktikan sesuai dengan Pasal 84 UUJN wajib membuktikan dugaan pelanggaran tersebut berdasarkan Pasal 163 HIR dan Pasal 1865 Kitab Undang-Undang Hukum Perdata. Notaris dapat dituntut penggantian biaya, ganti rugi, maupun bunga kepada notaris yang bersangkutan, apabila putusan pengadilan menyatakan akta tersebut memiliki kekuatan bukti akta di bawah tangan dan batal demi hukum. Notaris bisa mengajukan gugatan terkait hak dan kewajiban 
dalam hal tugas jabatannya, apabila gugatan ditolak

\section{b. Sanksi Administratif}

Sebagaimana telah diuraikan di atas mengenai pembahasan sanksi sanksi administratif dalam UUJN dikarenakan bahwa notaris sebagian dari kedudukannya merupakan pejabat umum yang harus tunduk pada hukum administrasi. Sanksisanksi yang diatur melalui Pasal 85 UUJN, diantaranya; sanksi teguran lisan, sanksi teguran tertulis, sanksi pemberhentian sementara, sanksi pemberhentian dengan hormat, dan sanksi pemberhentian dengan tidak hormat. Sanksi yang telah disebutkan di atas berlaku secara berjenjang dimulai dari teguran lisan sampai dengan pemberhentian dengan tidak hormat.

Apabila notaris melakukan pelanggaran yang bertentangan dengan pasal-pasal tertentu yang tersebut dalam Pasal 85 UUJN, yaitu ketentuan sebagaimana dimaksud dalam Pasal 7, Pasal 16 ayat (1) huruf a, Pasal 16 ayat (1). huruf b, Pasal 16 ayat (1) huruf c, Pasal 16 ayat (1) huruf d, Pasal 16 ayat (1) huruf e, Pasal 16 ayat (1) huruf f, Pasal 16 ayat (1) huruf g, Pasal 16 ayat (1) huruf h, Pasal 16 ayat (1) huruf i, Pasal 16 ayat (1) huruf j, Pasal 16 ayat (1) huruf k, Pasal 17, Pasal 20, Pasal 27, Pasal 32, Pasal 37, Pasal 54, Pasal 58, Pasal 59, dan/atau Pasal 63.

UUJN hanya mengatur sanksi administrasi (Philipus M. Hadjon 1983). Kedua sanksi tidak dapat diterapkan bersamaan, sesuai dengan Pasal 84 UUJN dan Pasal 85 UUJN. Demikian juga dengan sanksi pidana dan kode etik. Sanksi pidana dan kode etik berdiri sendiri dan dijatuhkan oleh instansi yang bersangkutan yaitu instansi yang diberikan kewenangan untuk menjatuhkan sanksi. Notaris diberhentikan sementara jabatannya jika terbukti melanggar Pasal 9 ayat 1 UUJN dan Pasal 12 UUJN, beberapa sanksi juga diterapkan seperti: Sanksi Perdata, Seperti: a. Pasal 9 ayat [1] huruf a UUJN; b. Pasal 12 huruf a UUJN.
Sanksi Pidana, seperti: 1. Dijatuhi hukuman pidana penjara berdasarkan putusan pengadilan yang telah mempunyai kekuatan hukum tetap dengan (ancaman) pidana penjara 5 (lima) tahun atau lebih sesuai dengan Pasal 13 UUJN. Sanksi Kode Etik, seperti: a. Pasal 9 ayat [1] huruf c UUJN; b. Pasal 12 huruf c UUJN. Sanksi Administartif, seperti: a. Pasal 9 ayat [1] huruf d UUJN; b. Pasal 12 huruf d UUJN.

Mekanisme penerapan sanksi administratif di terapkan instansi yang diberikan wewenang untuk menerapkan sekaligus penjatuhan sanksi dan sanksi perdata juga harus berdasar atas putusan pengadilan yang berkekuatan hukum tetap melalui amar putusan yang menghukum notaris untuk membayar biaya, ganti rugi dan bunga kepada penggugat. Penjatuhan baik sanksi administratif maupun sanksi perdata mempunyai bertujuan untuk mengevaluasi perbuatan Notaris. Dalam Pasal 12 huruf a UUJN penjatuhan sanksi pemberhentian secara tidak hormat terhadap notaris yang telah dinyatakan pailit berdasarkan atas putusan pengadilan yang memiliki kekuatan hukum tetap.

Proses kepailitan, notaris dijatuhi hukuman berupa sanksi administratif, yaitu pemberhentian sementara yang diatur telah diatur melalui Pasal 9 ayat (1) huruf a UUJN. Sebelum adanya putusan pemberhentian sementara, notaris yang bersangkutan dapat mengajukan pembelaan diri dengan menghadap Majelis Pengawas secara berskala. Dalam hal putusan dinyatakan pailit, bahwa permohonan pernyataan pailit ditolak, maka notaris yang bersangkutan dapat diangkat kembali menjadi notaris oleh Menteri setelah dipulihkan haknya atas dasar hukum yaitu; Pasal 10 Ayat (1) UUJN. Namun apabila putusan menetapkan bahwa notaris dinyatakan pailit, maka Majelis Pengawas Pusat mengusulkan kepada Menteri agar Notaris yang bersangkutan untuk diberhentikan dari jabatan dengan pemberhentian tidak hormat.

Akibat kepailitan menurut Pasal 12 huruf a UUJN juga berlaku secara khusus bagi notaris. Hal tersebut mengacu pada asas hukum Lex Specialist 
Derogat Legi Generalis yaitu hukum yang bersifat khusus mengesampingkan hukum yang bersifat umum, adalah salah satu asas preferensi yang ada dalam ilmu hukum. Asas preferensi adalah asas hukum yang memberikan pandangan bahwa hukum mana yang lebih untuk diberlakukan, ketika dalam suatu peristiwa hukum. Menurut Purnadi Purbacaraka dan Soerjono Soekanto maksud dari asas prefensi ialah bahwa peristiwa khusus wajib memberlakukan undang-undang yang bersifat khusus, walaupun untuk peristiwa khusus tersebut ada pula undang-undang yang menyebut peristiwa dan mengatur undang-undang yang lebih luas atau lebih umum, sehingga dapat mencakup peristiwa khusus tersebut (Purbacaraka, 1983).

Peraturan khusus mengenai jabatan notaris adalah Undang-Undang Nomor 30 Tahun 2004 sementara itu mengenai kepailitan diatur dalam Undang-Undang Nomor 37 Tahun 2004. Pasal 1 ayat (3) UUK dan PKPU. Selanjutnya dalam pada Pasal 1 ayat (6) UUK dan PKPU disebutkan bahwa utang adalah kewajiban yang dinyatakan dalam jumlah uang, baik dalam mata uang Indonesia atauoun mata uang asing, baik secara langsung ataupun yang kelak timbul dikemudian hari yang timbul akibat perjanjian atau undang-undang dan yang wajib dipenuhi oleh debitur, apabila tidak dipenuhi pemberian hak kepada kreditur untuk mendapat pemenuhannya dari harta kekayaan debitur.

Pasal 1 ayat (3) dan ayat (6) tersebut, maka menurut pendapat Joko Wilyono adalah benar. Bahwa bagi yang dinyatakan pailit harus memenuhi beberapa unsur yaitu adanya utang, selanjutnya utang tersebut timbul akibat dari perjanjian atau undang-undang yang dilakukan antara kedua belah pihak. Ganti kerugian yang dimaksud bukanlah utang, melainkan akibat hukum dari kelalaian atau kesalahan yang telah dilakukan oleh notaris. Sedangkan utang yang timbul dari adanya perjanjian yang sejak awal telah disepakatai oleh kedua belah pihak.
Sebab tidak dapat dijalankan karena terdapat perbedaan yaitu, kepailitan terhadap orang pribadi pengaturannya telah diatur oleh UUK dan PKPU sedangkan terhadap notaris yang dinyatakan pailit diatur melalui UUJN. Dalam UUK dan PKPU kepailitan timbul akibat adanya utang piutang yang timbul, berdasarkan perjanjian sedangkan dalam UUJN sebagai akibat hukum, sehingga apabila dia sebagai orang pribadi dinyatakan pailit, maka sesuai dengan UUK dan PKPU jabatannya sebagai notaris tidak dapat diberhentikan.

Berdasarkan uraian pembahasan tersebut diatas dapat diketahui bahwa tidak terdapat kesesuaian antara pengaturan pailit terhadap Jabatan Notaris yang diatur dalam UUJN dan kepailitan sebagaimana diatur dalam UU Kepailitan dan PKPU. Ketidak sesuaian tersebut didasarkan atas perbedaan yang mendasar yang terdapat dalam dua rumusan kepailitan tersebut, perbedaan itu seperti halnya mengenai subjek kepailitan dimana menurut UUJN subjek yang dikenai kepailitan adalah Notaris sebagai sebuah jabatan sedangkan dalam UU Kepailitan dan PKPU yang dapat dikenai kepailitan adalah seorang pribadi sebagai subjek hukum.

Perbedaan yang lain juga dapat dilihat dari penyebab terjadinya pailit dimana dalam kepailitan kepada Jabatan Notaris sebagaimana dimaksudkan dalam UUJN timbul akibat dari kewajiban untuk memberikan ganti kerugian akibat dari kesalahannya dalam menjalankan tugas jabatannya sebagai seorang Notaris yang berakibat kepada munculnya kerugian bagi pihak lain, berbeda dengan hal itu pailit yang pada umumnya dialami oleh seseorang sebagaimana dimaksud dalam UU Kepailitan dan PKPU timbul akibat ketidak mampuan seseorang untuk melakukan pelunasan terhadap utangnya. Untuk itu sudah sewajarnya bahwa kepailitan kepada Jabatan Notaris sebagaimana dimaksudkan dalam UUJN memiliki akibat hukum yang berbeda dengan kepailitan pada umumnya dialami oleh seseorang sebagai subjek hukum 
dalam UU Kepailitan dan PKPU yaitu pemberhentian Notaris secara tidak hormat.

\section{Simpulan}

Ruang lingkup pailit bagi Notaris berdasarkan UUJN tidak sesuai dengan ruang lingkup pailit berdasarkan UUK dan PKPU. Ruang lingkup kepailitan dalam UUJN dapat meliputi jabatan dari debitur yang mengalami pailit berdasarkan putusan pengadilan yang memperoleh kekuatan hukum tetap. Sedangkan ruang lingkup kepailitan berdasarkan UUK dan PKPU adalah benda, segala sesuatu yang didapatkan oleh debitur dari pekerjaannya sendiri sebagai penggajian atau dari suatu jabatan atau jasa sebagai upah, pensiun, uang tunggu atau uang tunjangan, sejauh yang ditentukan oleh hakim pengawas, uang yang diberikan kepada debitur untuk memenuhi suatu kewajiban memberi nafkah berdasarkan ketentuan undang-undang.

Akibat hukum yang dapat diterima oleh Notaris yang dinyatakan pailit adalah pemberhentian jabatan sebagai seorang Notaris. Hal ini didasarkan ketentuan Pasal 12 huruf a UUJN yang memberikan lebih dari satu akibat hukum terhadap notaris tersebut. Notaris dapat dituntut pemenuhan penggantian biaya, ganti rugi maupun bunga oleh para pihak atas dasar perbuatan melawan hukum sebagaimana diatur dalam Pasal 1365 KUH Perdata dan manakala notaris tersebut berada dalam keadaan insolvensi dikarenakan ketidakmampuan notaris dalam memenuhi kewajibannya maka notaris dinyatakan pailit berdasarkan putusan pengadilan.

\section{Daftar pustaka}

Adjie, Habib. 2008. Hukum Notaris Indonesia. Refika Aditama. Bandung.

Adjie, Habib. 2008. Sanksi Perdata dan Administratif Terhadap Notaris Sebagai Pejabat Publik. Refika Aditama. Bandung.
Firmansyah, Y.R., 2017. Kekuatan Hukum Akta Perdamaian yang Dibuat Dihadapan Notaris dan Putusan Akta Perdamaian Pengadilan. Jurnal Cakrawala Hukum, 8(2), pp.220-229.

Hadjon, Philipus M. 1993. Pemerintah Menurut Hukum (Wet-En Rechmatig Bestuur). Ctk. Pertama. Yuridika. Surabaya.

Kitab Undang-Undang Hukum Perdata.

Pratiwi, R.O., 2020. Perlindungan hukum bagi penerima wasiat terhadap notaris yang tidak melaporkan akta wasiat secara elektronik. Jurnal Cakrawala Hukum, 11(3).

Purbacaraka, Purnadi., dkk. 1983. Perundang-Undangan dan Yurisprudensi. Citra Aditya Bakti. Bandung.

Purwaningsih, Endang. 2011, Penegakan Hukum Jabatan Notaris Dalam Pembuatan Perjanjian Berdasarkan Pancasila Dalam Rangka Hukum. Jurnal ADIL, Jurnal Hukum Fakultas Hukum Yarsi. Vol. 2. No. 3 Desember 2011. Jakarta.

Semedi, Bambang. 2013. Penegakan Hukum Yang Menjamin Kepastian Hukum. Artikel Pusdiklat Bea dan Cukai. Jakarta.

Shubhan, M. Hadi. 2008. Hukum Kepailitan. Kencana Prenada Media Group. Jakarta.

Sudarsono. 2007. Kamus Hukum Edisi Baru. ctk. Kelima. Penerbit Rineka Cipta. Jakarta.

Sutcipto, H.M.N. Purwo. 1995. Pengertian Pokok Hukum Dagang Indonesia Jilid 1, Pengetahuan Dasar Hukum Dagang. Djambatan. Jakarta.

Sutedi, Adrian. 2009. Hukum Kepailitan. Ghalia Indonesia. Bogor,

Undang-Undang Republik Indonesia Nomor 2 Tahun 2014 Tentang Perubahan Atas Undang-Undang Republik Indonesia Nomor 30 Tahun 2004 Tentang Jabatan Notaris.

Undang-Undang Republik Indonesia Nomor 30 Tahun 2004 tentang Jabatan Notaris.

Undang-Undang Republik Indonesia Nomor 37 Tahun 2004 tentang Kepailitan dan Penundaan Kewajiban Pembayaran Utang.

Wisnuwardhani, D.A., 2017. Implementasi Hak Pekerja Dalam Hal Upah di Kantor Notaris. Jurnal Cakrawala Hukum, 8(1), pp.33-43. 